\title{
Regulation of rat Sertoli cell function by FSH: possible role of phosphatidylinositol 3-kinase/protein kinase B pathway
}

\author{
S B Meroni, M F Riera, E H Pellizzari and S B Cigorraga \\ Centro de Investigaciones Endocrinológicas (CEDIE), Hospital de Niños 'R Gutiérrez', Gallo 1330, (1425) Buenos Aires, Argentina \\ (Requests for offprints should be addressed to S B Cigorraga; Email: scigorraga@cedie.org.ar)
}

\begin{abstract}
The FSH molecular mechanism of action is best recognized for its stimulation of the adenylyl cyclase/cAMP pathway via activation of a $G$ protein. Recently, links between cAMP, phosphatidylinositol 3-kinase (PI3K) and protein kinase $\mathrm{B}(\mathrm{PKB})$ signaling pathways in thyroid and granulosa cells have been observed. The aim of this study was to investigate the possible role of the PI3K/PKB pathway in FSH regulation of Sertoli cell function. Twenty-day-old rat Sertoli cell cultures were used. An increase in phosphorylated PKB (P-PKB) levels in response to FSH and dibutyryl-cAMP was observed. These increments in P-PKB levels were not observed in the presence of two PI3K inhibitors, wortmannin and Ly 294002. Inhibition of protein kinase A (PKA) by H89 did not decrease FSH stimulation of P-PKB levels. Taken
\end{abstract}

together, these results indicate that FSH increases P-PKB levels in a PI3K-dependent and PKA-independent manner in rat Sertoli cells. In addition, wortmannin partially inhibited the ability of FSH to stimulate two well-known parameters of Sertoli cell function - transferrin secretion and lactate production - at doses equal to or lower than $0 \cdot 1 \mu \mathrm{M}$. Related to lactate production, a decrease in FSH stimulation of lactate dehydrogenase activity and of basal and FSH-stimulated glucose uptake was observed in the presence of wortmannin. These metabolic changes were in most cases accompanied by changes in the levels of P-PKB. Altogether, these results suggest a meaningful role of the PI3K/PKB pathway in the mechanism of action of FSH in rat Sertoli cells.

Journal of Endocrinology (2002) 174, 195-204

\section{Introduction}

Androgens and the pituitary gonadotropin folliclestimulating hormone (FSH) control Sertoli cell function. In addition, their effects are modulated by the action of a large set of locally produced factors that include growth factors and cytokines (Gnessi et al. 1997). The complex mechanisms by which cells respond to hormonal stimuli are often dependent on several signal transduction pathways that lead to the activation of specific biological responses. The FSH molecular mechanism of action is best recognized for its stimulation of the adenylyl cyclase/cAMP pathway via activation of a $G$ protein. Elevated cAMP levels lead to the activation of protein kinase A (PKA) that phosphorylates several protein substrates. This cascade has been extensively analyzed for the mechanism of action of FSH and of other pituitary hormones such as luteinizing hormone, thyrotropin (TSH) and adrenocorticotropin. As for the mechanism of action of FSH in Sertoli cells, in addition to the cAMP/PKA pathway, other signaling events that include increased intracellular $\mathrm{Ca}^{2+}$ levels (Grasso \& Reichert 1989, Gorczynska \& Handelsman 1991), activation of phospholipase $A_{2}$ (Jannini et al. 1994) and nuclear factor kappa B (NFkB) translocation (Delfino \& Walker
1998) have been demonstrated. Even though it has been demonstrated that there is no phosphoinositide turnover in response to FSH stimulation in Sertoli cells (Monaco et al. 1988), it has been shown that a protein kinase C (PKC)dependent pathway can modulate Sertoli cell response to FSH (Lambert et al. 1991, Meroni et al. 1997).

Protein kinase B (PKB), also referred to as Akt or RAC kinase, is a serine/threonine protein kinase which was cloned by virtue of its homology to the $\mathrm{A}$ and $\mathrm{C}$ protein kinases, and is the cellular homolog of the product of the $v$-akt oncogene (Bellacosa et al. 1991, Coffer \& Woodgett 1991, Jones et al. 1991). This kinase is activated in response to polypeptides acting through tyrosine kinase receptors such as platelet-derived growth factor, insulin, basic fibroblast growth factor and epidermal growth factor in a pathway involving phosphatidylinositol 3-kinase (PI3K) (Coffer et al. 1998). Protein kinase B contains an amino terminal pleckstrin homology domain that binds phosphorylated lipids at the membrane in response to activation of PI3K. In this way, PKB is activated by phospholipid binding and phosphorylation at Thr 308 and Ser 473 by specific kinases (Alessi et al. 1996). Activation of PKB by PI3K-independent mechanisms has also been described (Filippa et al. 1999). 
Recently, links between G-protein-coupled receptors, cAMP, PI3K and PKB signaling pathways have been observed. Cass et al. (1999) have shown that TSH upon binding to its respective G-protein-coupled receptor and via cAMP (but not PKA) stimulates the phosphorylation of $\mathrm{PKB}$ in a PI3K-dependent pathway in a thyroid cell line. In addition, Gonzalez-Robayna et al. (2000) have presented evidence that in granulosa cells FSH increases PKB phosphorylation and activation in a way that is cAMPdependent, PKA-independent but PI3K-dependent.

Signal transduction pathways for an individual hormone vary from cell to cell. In addition, signal transduction pathways for an individual hormone vary within the same cell type with the maturation state of the cell. It is worth mentioning that MAP kinase (MAPK) activation in response to FSH has been observed in granulosa cells (Cameron et al. 1996, Das et al. 1996, Moore et al. 2001), while in 20-day-old Sertoli cells FSH decreases the levels of activated MAPK (Crepieux et al. 2001). These experiments clearly show that even when Sertoli cells are considered the male counterpart of granulosa cells they do not have the same intracellular machinery. A major issue in understanding FSH physiological function in males is to define signaling pathways that allow the hormone to guide its target cells towards differentiation. As mentioned before, it has recently been demonstrated that PI3K/PKB activation is involved in the regulation of granulosa cells by FSH. However, the possibility that a PI3K/PKB pathway may be involved in the mechanism(s) that FSH utilizes to regulate 20-day-old Sertoli cell function has not yet been explored. The aim of the present study was to investigate whether FSH regulation of Sertoli cell function may involve a PI3K/PKB-dependent pathway.

\section{Materials and Methods}

\section{Materials}

Ovine FSH (NIH-oFSH-S-16) was obtained from the National Hormone and Pituitary Program, National Institute of Diabetes, Digestive and Kidney Diseases (NIDDK), Bethesda, MD, USA. Wortmannin, Ly 294002 and H89 were purchased from Biomol (Plymouth Meeting, PA, USA). [2,6- $\left.{ }^{3} \mathrm{H}\right]-2-$ Deoxy-D-glucose ([2,6$\left.{ }^{3} \mathrm{H}\right]-2-\mathrm{DOG}$ ) was obtained from NEN (Boston, MA, USA). Kodak X-Omat $S$ films were purchased from Eastman Kodak (Rochester, NY, USA). All other drugs and reagents were obtained from Sigma-Aldrich (St Louis, MO, USA).

\section{Sertoli cell isolation and culture}

Sertoli cells from 20-day-old Sprague-Dawley rats were isolated as previously described (Meroni et al. 1999). Briefly, decapsulated testes were digested with $0 \cdot 1 \%$ collagenase and $0 \cdot 006 \%$ soybean trypsin inhibitor in Hanks balanced salt solution for $5 \mathrm{~min}$ at room temperature. Seminiferous tubules were saved, cut and submitted to $1 \mathrm{M}$ glycine-2 mM EDTA ( $\mathrm{pH} 7 \cdot 4$ ) treatment to remove peritubular cells. The washed tubular pellet was then digested again with collagenase for $10 \mathrm{~min}$ at room temperature to remove germinal cells. The Sertoli cell suspension, collected by sedimentation, was resuspended in culture medium which consists of a 1:1 mixture of Ham F12 and Dulbecco's modified Eagle's medium, supplemented with $20 \mathrm{mM}$ HEPES, $100 \mathrm{IU} / \mathrm{ml}$ penicillin, $2.5 \mu \mathrm{g} / \mathrm{ml}$ amphotericin $\mathrm{B}, 1.2 \mathrm{mg} / \mathrm{ml}$ sodium bicarbonate, $10 \mu \mathrm{g} / \mathrm{ml}$ transferrin, $5 \mu \mathrm{g} / \mathrm{ml}$ insulin, $5 \mu \mathrm{g} / \mathrm{ml}$ vitamin $\mathrm{E}$ and $4 \mathrm{ng} / \mathrm{ml}$ hydrocortisone. Sertoli cells were cultured in 6-, 24- or 96-multiwell plates $(5 \mu \mathrm{g}$ DNA $/ \mathrm{cm}^{2}$ ) at $34{ }^{\circ} \mathrm{C}$ in a mixture of $5 \% \mathrm{CO}_{2}: 95 \%$ air.

No myoid cell contamination was revealed in the cultures when an immunoperoxidase technique was applied to Sertoli cell cultures using a specific antiserum to alpha smooth muscle actin. Remaining cell contaminants were of germ cell origin and this contamination was below $5 \%$ after $48 \mathrm{~h}$ in culture as examined by phase contrast microscopy.

\section{Culture conditions}

Sertoli cells were allowed to attach for $48 \mathrm{~h}$ in the presence of insulin, and medium was replaced at this time with fresh medium without insulin; variable doses of FSH were added on day 3 as indicated in the Figure legends. The 72-h conditioned media obtained on day 6 were used to evaluate transferrin and lactate levels. Cells harvested on day 6 were used to determine gamma glutamyl transpeptidase $(\gamma-\mathrm{GTP})$ and lactate dehydrogenase (LDH) activities and to evaluate cell viability.

Cells harvested on day 6 , pretreated as indicated in the Figure legends, were also used for Western blot analysis of phosphorylated PKB (P-PKB) levels. Cultures obtained under identical conditions were used to analyze intracellular cAMP levels stimulated by FSH. For glucose uptake studies, cells harvested on day 5 , pretreated as described in the Figure legends, were used.

\section{Transferrin determination}

Rat transferrin (rTF) was measured by RIA as described by Handelsman et al. (1989). A polyclonal antibody raised against rTF in rabbits was used (Cappel Laboratories, Cochranville, PA, USA). The cross-reactivity of human transferrin (TF) in this assay is less than $0.003 \%$. Unconditioned medium containing $10 \mu \mathrm{g} / \mathrm{ml}$ human TF did not show any cross-reactivity in this assay. This RIA has a sensitivity of $3 \mathrm{ng} / \mathrm{tube}$ and intra- and interassay coefficients of variation were $7 \%$ and $16 \%$ respectively. 


\section{$\gamma$-Glutamyl transpeptidase assay}

$\gamma$-GTP activity was assayed by the method of Orlowsky \& Meister (1963), using L- $\gamma$-glutamyl $p$-nitroanilide as substrate and glycylglycine as the acceptor molecule. Sertoli cell monolayers were disrupted by ultrasonic irradiation in $0.5 \mathrm{ml}$ reaction buffer $\left(0.1 \mathrm{M}\right.$ Tris buffer, $0.01 \mathrm{M} \mathrm{MgCl}_{2}$, $0.02 \mathrm{M}$ glycylglycine, $\mathrm{pH}$ 9). Adequate aliquots for DNA determinations were saved and $5 \mathrm{mM}$ substrate (L- $\gamma-$ glutamyl $p$-nitroanilide) were added to the remaining material. The reaction was allowed to proceed for $120 \mathrm{~min}$ at $34{ }^{\circ} \mathrm{C}$, and the enzymatic reaction was stopped by addition of acetic acid up to a $1 \mathrm{M}$ concentration. Samples were then centrifuged and absorbances determined in a spectrophotometer at $410 \mathrm{~nm}$. Values were compared against a standard curve with increasing concentrations of $p$-nitroaniline.

\section{Lactate determination}

Lactate was measured by a standard method involving conversion of $\mathrm{NAD}^{+}$to NADH determined as the rate of increase of absorbance at $340 \mathrm{~nm}$. A commercial kit from Sigma-Aldrich was used.

\section{Measurement of 2-deoxy-D-glucose uptake}

Glucose transport was studied using the uptake of the labeled nonmetabolizable glucose analog 2-deoxyD-glucose (2-DOG). Cells that had received different treatments for variable periods of time $(0 \cdot 5-48 \mathrm{~h})$, as indicated in the Figure legends, were used. After treatment, culture media were discarded and cells were washed three times with glucose-free phosphate-buffered saline (PBS) at room temperature. Then, Sertoli cells were incubated at $34^{\circ} \mathrm{C}$ in $0.5 \mathrm{ml}$ glucose-free PBS containing [2,6- $\left.{ }^{3} \mathrm{H}\right]-2-D O G(0.5 \mu \mathrm{Ci} / \mathrm{ml})$ for $30 \mathrm{~min}$. Unspecific uptake was determined in incubations performed in the presence of a 10000 -fold higher concentration of unlabeled 2-DOG. At the end of the incubation period, dishes were placed on ice and extensively washed with ice-cold PBS until no radioactivity was present in the washings. Cells were then dissolved with $0.5 \mathrm{M}$ sodium hydroxide, $0.4 \% \mathrm{w} / \mathrm{v}$ sodium deoxycholate and counted in a liquid scintillation spectrophotometer. Parallel cultures receiving identical treatments to those performed before the glucose uptake assay were used for DNA determinations. Results were expressed on a per $\mu \mathrm{g}$ DNA basis.

\section{LDH activity measurement}

After incubation of Sertoli cells in the absence or presence of the different stimuli, culture media were saved and cells were disrupted by ultrasonic irradiation in $\mathrm{NaCl} 0.9 \% \mathrm{w} / \mathrm{v}$ and centrifuged $(15800 \mathrm{~g}, 10 \mathrm{~min})$. The supernatant was used to measure total LDH activity. Total LDH activity was determined by a routinely used spectrophotometric method (Randox Laboratories, Crumlin, Co. Antrim, $\mathrm{UK})$.

\section{Cell extracts and Western blot analysis}

On day 6, cells cultured on 6-well plates and pretreated for variable periods of time as indicated in the Figure legends were washed once with PBS at room temperature. Then, $200 \mu \mathrm{l}$ PBS containing $20 \mu \mathrm{l}$ of a protease inhibitor cocktail from Sigma (P-8340) and $2 \mathrm{mM}$ phenylmethylsulfonylfluoride were added to the cells. Cells were then placed on ice and disrupted by ultrasonic irradiation. A $200 \mu \mathrm{l}$ volume of $2 \times$ Laemmli buffer (4\% w/v SDS, $20 \%$ $\mathrm{v} / \mathrm{v}$ glycerol, $10 \% \mathrm{v} / \mathrm{v} 2-$ mercaptoethanol, $0 \cdot 004 \% \mathrm{w} / \mathrm{v}$ bromophenol blue and $0.125 \mathrm{M}$ Tris- $\mathrm{HCl}, \mathrm{pH}$ 6.8) was added and thoroughly mixed (Laemmli 1970). Samples were immersed in a boiling water bath for $5 \mathrm{~min}$ and then immediately settled on ice. Proteins were resolved in $10 \%$ SDS-PAGE (10\% acrylamide/bisacrylamide for the resolving gel and $4 \cdot 3 \%$ acrylamide/bisacrylamide for the stacking gel) in a Mini Protein II Cell (Bio-Rad, Hercules, CA, USA). After SDS-PAGE, gels were equilibrated in transfer buffer for $10 \mathrm{~min}$ and electrotransferred at $100 \mathrm{~V}$ for 60 min onto PVDF membranes (Hybond-P, Amersham Pharmacia Biotech, UK) using a Mini Trans-Blot Cell (Bio-Rad). Membranes were probed with a commercial kit (Phosphoplus Akt Ser 473 antibody kit, New England Biolabs Inc., Beverley, MA, USA) that allows specific recognition of both non-phosphorylated and serinephosphorylated PKB. The intensities of the autoradiographic bands were estimated by densitometric scanning using NIH Image (Scion Corporation Frederick, MD, USA) software.

\section{Cell viability test}

A cell viability test was performed in cells cultured on 96-well plates and treated for $90 \mathrm{~min}$ or $72 \mathrm{~h}$ with H89, Ly 294002 or wortmannin. A commercial kit (CellTiter 96 Aqueous Non-Radioactive Cell Proliferation Assay, Promega Corporation) was used.

\section{Other assays}

cAMP was determined by RIA using a specific antibody. The RIA has a sensitivity of $25 \mathrm{fmol} /$ tube and intra- and interassay coefficients of variation of 9 and $17 \%$ respectively. DNA was determined by the method of Labarca \& Paigen (1980).

\section{Statistical analysis}

To analyze data from glucose uptake studies, cell viability, lactate, transferrin and cAMP production, and $\gamma-G T P$ and 
A

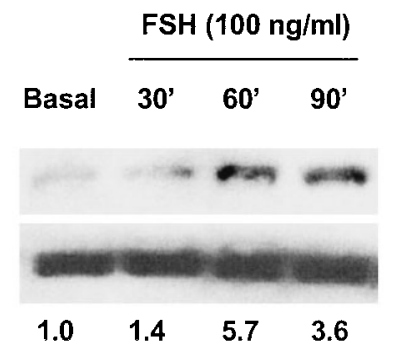

B FSH (ng/ml)
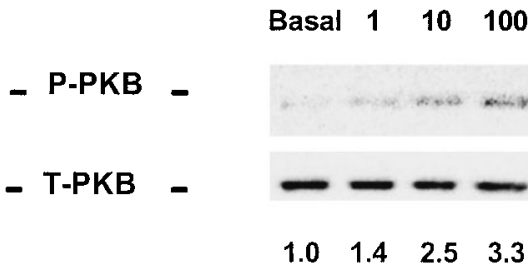

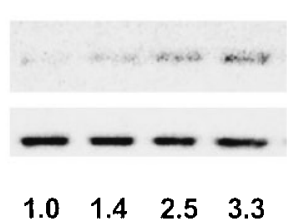

C

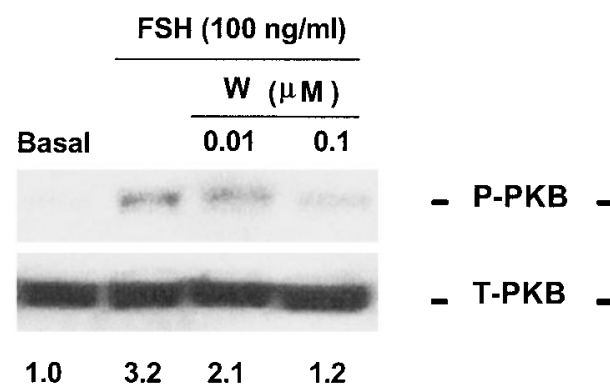

D

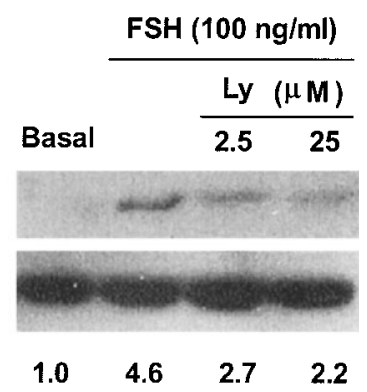

Figure 1 FSH increases the levels of phosphorylated protein kinase B (P-PKB) in rat Sertoli cells. (A) Sertoli cells were stimulated for variable periods of time $(30,60$ or $90 \mathrm{~min})$ with $100 \mathrm{ng} / \mathrm{ml} \mathrm{FSH}$. (B) Sertoli cells were incubated for $60 \mathrm{~min}$ in the absence or presence of variable doses of $\mathrm{FSH}(1,10$ and $100 \mathrm{ng} / \mathrm{ml} \mathrm{FSH})$. (C) Sertoli cells were stimulated for 60 min with $100 \mathrm{ng} / \mathrm{ml} \mathrm{FSH}$ in the absence or presence of two different doses of wortmannin (W; $0 \cdot 01$ and $0 \cdot 1 \mu \mathrm{M}$ ). (D) Sertoli cells were stimulated for 60 min with $100 \mathrm{ng} / \mathrm{ml} \mathrm{FSH}$ in the absence or presence of two different doses of Ly 294002 (Ly; 2.5 and $25 \mu \mathrm{M})$. Cell extracts were prepared the designated intervals and utilized for Western blot analysis using antibodies specific for PKB (T-PKB) or P-PKB. Numbers at the bottom of each lane in this and subsequent Figures for PKB indicate the fold increase in phosphorylation (ratio of P-PKB to T-PKB in each sample) relative to basal. Results are representative of two reproducible experiments per treatment group.

LDH activity, one-way analysis of variance (ANOVA) followed by the Tukey-Kramer test for multiple comparisons using the GB-STAT version 4.0 statistical program (Dynamic Microsystems Inc., Silver Spring, MD, USA) was performed. Probabilities $<0 \cdot 01$ were considered statistically significant.

\section{Results}

$P K B$ is phosphorylated in rat Sertoli cells stimulated with FSH and dibutyryl-cAMP (dbcAMP) in a PI3K-dependent manner

Sertoli cell cultures were stimulated for variable periods of time (30, 60 and $90 \mathrm{~min}$ ) with $100 \mathrm{ng} / \mathrm{ml} \mathrm{FSH}$ and for $60 \mathrm{~min}$ with variable doses of FSH $(1,10$ and $100 \mathrm{ng} / \mathrm{ml})$. A low level of P-PKB in basal cultures was observed. Stimulation of the cultures with $100 \mathrm{ng} / \mathrm{ml} \mathrm{FSH}$ showed time-dependent increments in P-PKB levels reaching maximal stimulus in 60-min incubations (Fig. 1A). Doseresponse studies in 60-min incubations showed a maximal response with $100 \mathrm{ng} / \mathrm{ml} \mathrm{FSH} \mathrm{(Fig.} \mathrm{1B).} \mathrm{Pooled} \mathrm{data}$ obtained in eight individual experiments performed in 60-min incubations with $100 \mathrm{ng} / \mathrm{ml}$ FSH revealed $4 \pm 0 \cdot 8$-fold stimulation (mean \pm S.E.) in P-PKB levels.

In order to evaluate the participation of PI3K in the observed stimulatory effects of FSH on P-PKB levels, cells pre-incubated for 15 min with two well-known PI3K inhibitors, wortmannin and Ly 294002, were stimulated with FSH for $60 \mathrm{~min}$. Figure 1C shows that wortmannin dose-dependently decreased the ability of FSH to increase the levels of P-PKB. Figure 1D shows that Ly 294002 produced similar effects. These inhibitors did not modify the low levels of P-PKB present under basal conditions (data not shown). 
Table 1 Effect of different doses of FSH on Sertoli cell intracellular cAMP levels. On day 6, Sertoli cells were stimulated for $60 \mathrm{~min}$ with 1,10 or $100 \mathrm{ng} / \mathrm{ml} \mathrm{FSH}$. Intracellular cAMP levels were determined after this incubation period. Results represent means \pm S.D. of triplicate incubations in one representative experiment out of two

\begin{tabular}{lc} 
& $\begin{array}{l}\text { Intracellular cAMP } \\
(\mathrm{fmol} / \mu \mathrm{g} D N A)\end{array}$ \\
\cline { 2 - 2 } $\begin{array}{l}\text { Dose of } \\
\text { FSH }(\mathrm{ng} / \mathrm{ml})\end{array}$ & \\
Basal & $142 \cdot 4 \pm 9 \cdot 6^{\mathrm{a}}$ \\
1 & $254 \cdot 4 \pm 56 \cdot 9^{\mathrm{b}}$ \\
10 & $442 \cdot 0 \pm 99 \cdot 7^{\mathrm{c}}$ \\
100 & $2439 \cdot 5 \pm 566 \cdot 6^{\mathrm{d}}$ \\
\hline
\end{tabular}

Different letters indicate statistically significant differences $(P<0 \cdot 01)$.

We next examined whether a cAMP/PKA-dependent pathway mediated the increment in P-PKB levels. Table 1 shows that FSH stimulated intracellular cAMP levels in a dose-dependent manner at doses that also stimulated P-PKB levels. Therefore, we next examined whether a cAMP analog mimicked the effect of FSH. Figure 2A shows that the cAMP analog dbcAMP stimulated the levels of P-PKB. The latter Figure also shows that the effect on the levels of P-PKB produced by the cyclic nucleotide was not present in cells pre-incubated with the two inhibitors of PI3K. In addition, Fig. 2B shows that the specific PKA inhibitor, H89, increased basal levels of $\mathrm{P}-\mathrm{PKB}$ and it also increased P-PKB levels stimulated by FSH.

Cells incubated for $15 \mathrm{~min}$ with H89, wortmannin and Ly 294002 and then stimulated with FSH or dbcAMP for $60 \mathrm{~min}$ did not show modifications in cell viability (data not shown).

\section{PI3K activity participates in FSH regulation of Sertoli cell $\gamma$-GTP activity and transferrin secretion}

The next set of experiments were intended to analyze the relevance of PI3K activity on two Sertoli cell biological responses to FSH largely considered to occur via a cAMP/PKA pathway. The PKA inhibitor, $\mathrm{H} 89$, and the PI3K inhibitors, wortmannin and Ly 294002, were added to the cultures $15 \mathrm{~min}$ prior to the initiation of a $72-\mathrm{h}$ incubation period with FSH. A cell viability test performed at the end of this 72-h period showed that H89 and Ly 294002 decreased cell viability in long-term incubations (Table 2). As a consequence, for those biological responses obtained in long-term incubations only the effect of wortmannin was analyzed.

Figure 3 shows that while a $1 \mu \mathrm{M}$ dose of wortmannin was necessary to partially inhibit the ability of FSH to stimulate $\gamma$-GTP activity (A), a dose-dependent decrease in transferrin secretion starting at $0.01 \mu \mathrm{M}$ wortmannin was observed (B). Wortmannin did not modify $\gamma$-GTP
A

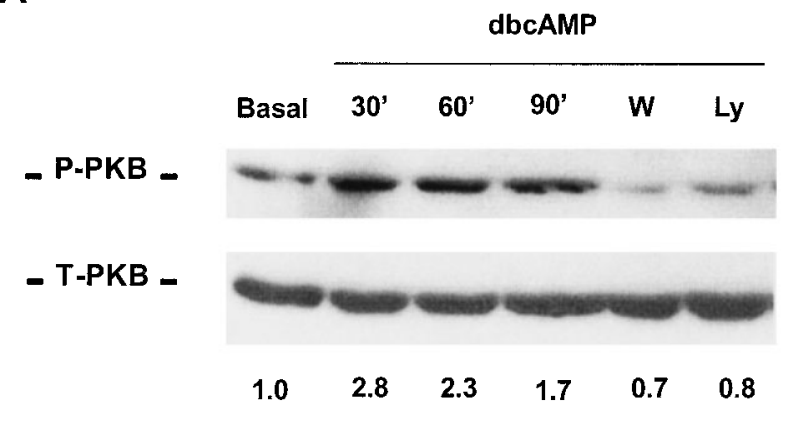

B

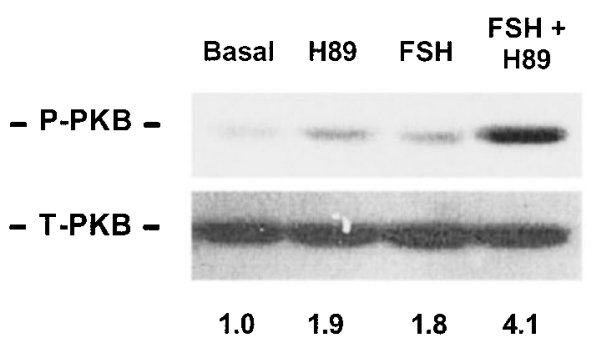

Figure $2 \mathrm{FSH} / \mathrm{CAMP}$ promotes phosphorylation of $\mathrm{PKB}$ in a phosphatidylinositol 3-kinase (PI3K)-dependent and protein kinase A (PKA)-independent manner. (A) Sertoli cells were maintained under basal conditions or stimulated for 30,60 or 90 min with $1 \mathrm{mM}$ dibutyryl cAMP (dbcAMP). In addition, cells were stimulated for $60 \mathrm{~min}$ with $1 \mathrm{mM}$ dbcAMP in the presence of $1 \mu \mathrm{M}$ wortmannin (W) or $25 \mu \mathrm{M}$ Ly 294002 (Ly). (B) Sertoli cells were maintained under basal or FSH-stimulated $(100 \mathrm{ng} / \mathrm{ml})$ conditions in the absence or presence of $10 \mu \mathrm{M} \mathrm{H} 89$ for $60 \mathrm{~min}$. Cell extracts were prepared at the designated intervals and utilized for Western blot analysis using antibodies specific for PKB (T-PKB) or phosphorylated PKB (P-PKB). Results are representative of two experiments giving identical results.

Table 2 Effect of wortmannin Ly, 294002 and H89 on Sertoli cell viability. Sertoli cells were incubated for 72 hours (day 3 to day 6) without (Control) or with $1 \mu \mathrm{M}$ wortmannin (W), $25 \mu \mathrm{M}$ Ly 294002 (Ly) or $10 \mu \mathrm{M} \mathrm{H} 89$ in the absence (Basal) or presence of $100 \mathrm{ng} / \mathrm{ml} \mathrm{FSH}$. The cell viability assay was performed on day 6 . Data are expressed as percentage of the control under basal conditions and are presented as means \pm S.D. of triplicate incubations in one representative experiment out of three

\begin{tabular}{lll} 
& \multicolumn{2}{l}{$\begin{array}{l}\text { Cell viability } \\
\text { (\% of control) }\end{array}$} \\
\cline { 2 - 2 } & \multicolumn{1}{c}{ Basal } & FSH \\
Control & 100 & $97 \pm 7$ \\
W $(1 \mu \mathrm{M})$ & $96 \pm 6$ & $97 \pm 7$ \\
Ly $(25 \mu \mathrm{M})$ & $52 \pm 4^{*}$ & $63 \pm 4^{*}$ \\
H89 $(10 \mu \mathrm{M})$ & $85 \pm 6$ & $72 \pm 5^{*}$ \\
\hline
\end{tabular}

${ }^{*} P<0 \cdot 01$ vs Control. 
A

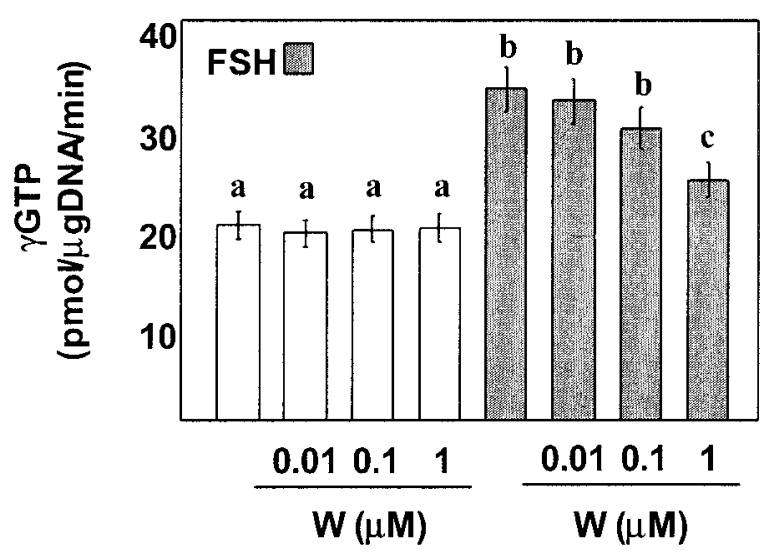

B

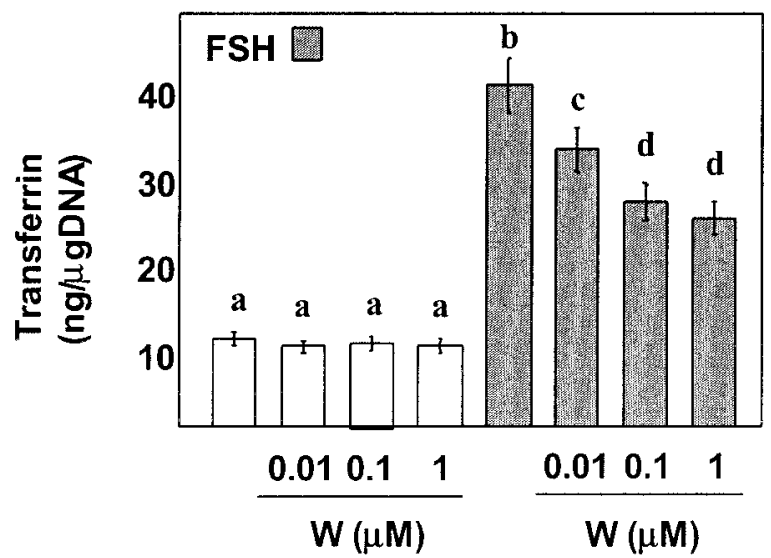

Figure 3 Wortmannin inhibits FSH stimulation of Sertoli cell $\gamma$-glutamyl transpeptidase ( $\gamma$-GTP) activity and transferrin secretion. Sertoli cells were stimulated for $72 \mathrm{~h}$ (day 3 to day 6 ) with $100 \mathrm{ng} / \mathrm{ml} \mathrm{FSH}$ in the absence or presence of different doses of wortmannin (W). (A) $\gamma$-GTP activity was determined in cells harvested on day 6. (B) Transferrin was determined in the 72-h conditioned media recovered on day 6 . Results represent means \pm S.D. of triplicate incubations in one representative experiment out of three. Different letters indicate statistically significant differences $(P<0 \cdot 01)$.

activity and transferrin secretion under basal experimental conditions at any dose tested.

\section{PI3K activity participates in FSH regulation of Sertoli cell lactate production}

In addition to the effects of wortmannin on FSHstimulated $\gamma$-GTP activity and transferrin secretion, Fig. 4A shows that this PI3K inhibitor decreased FSHstimulated lactate production at a $0 \cdot 1 \mu \mathrm{M}$ concentration. Wortmannin did not modify basal lactate secretion at any dose tested.
We have previously shown (Riera et al. 2001) that increments in LDH activity and in glucose uptake are part of the mechanisms utilized by FSH to increase lactate production. Therefore, we next examined the possibility that PI3K activity was involved in the regulation of these biochemical steps that are targets for FSH action in Sertoli cells. Figure 4B shows that wortmannin $(0 \cdot 1 \mu \mathrm{M})$ decreased the ability of FSH to stimulate LDH activity. Wortmannin did not modify basal LDH activity.

As for glucose uptake, Table 3 shows that the PKA inhibitor, H89, did not modify glucose uptake under basal or FSH-stimulated conditions. In addition, this Table shows that cycloheximide, a protein synthesis inhibitor, did not modify glucose uptake stimulated by FSH in a $60-$ min incubation period.

Finally, Fig. 4C shows that wortmannin markedly decreased basal and FSH-stimulated glucose uptake.

\section{Discussion}

The gonadotropin FSH plays a key role in the control of Sertoli cell function. FSH determines the number of Sertoli cells that will be present in adult males by its ability to control proliferation at the neonatal stage (Orth 1982). In the rat, Sertoli cell mitosis ceases by day 15 and FSH then takes control of differentiation of these cells that are essential to sustain a qualitatively and quantitatively normal spermatogenesis (Griswold 1993). FSH initiates its action through binding to specific G-coupled receptors that activate adenylyl cyclase resulting in the elevation of intracellular cAMP levels and PKA activation. Other signaling pathways that have been shown to participate in the mechanism of action of FSH have been reviewed in the Introduction. The study of possible signal transduction pathways utilized by FSH different from the classic cAMP/PKA pathway, and the analysis of a possible correlation between their activation and the biological responses elicited are under investigation.

PI3K is a key enzyme implicated in the regulation of a broad array of biological responses including receptorstimulated mitogenesis, oxidative burst, membrane ruffling and glucose uptake (Rameh \& Cantley 1999). At least two types of PI3K, in terms of mode of activation, have been described in mammalian cells. One is stimulated by membrane-bound receptors activating tyrosine kinase (Porter \& Vaillancourt 1998), whereas the other is under the direct control of the heterotrimeric GTPbinding proteins (Tang \& Downes 1997). Agoniststimulated PI3K generates specific inositol phospholipids that are recognized by a subset of proteins that contain pleckstrin homology (PH) domains, a specialized lipidbinding module. Protein kinase $\mathrm{B}$ was among the first proteins known to contain a $\mathrm{PH}$ domain. This $\mathrm{PH}$ domain of PKB specifically binds PI3K lipid products, and a firm link between PI3K and PKB signaling has now been established (Vanhaesebroeck \& Alessi 2000). 

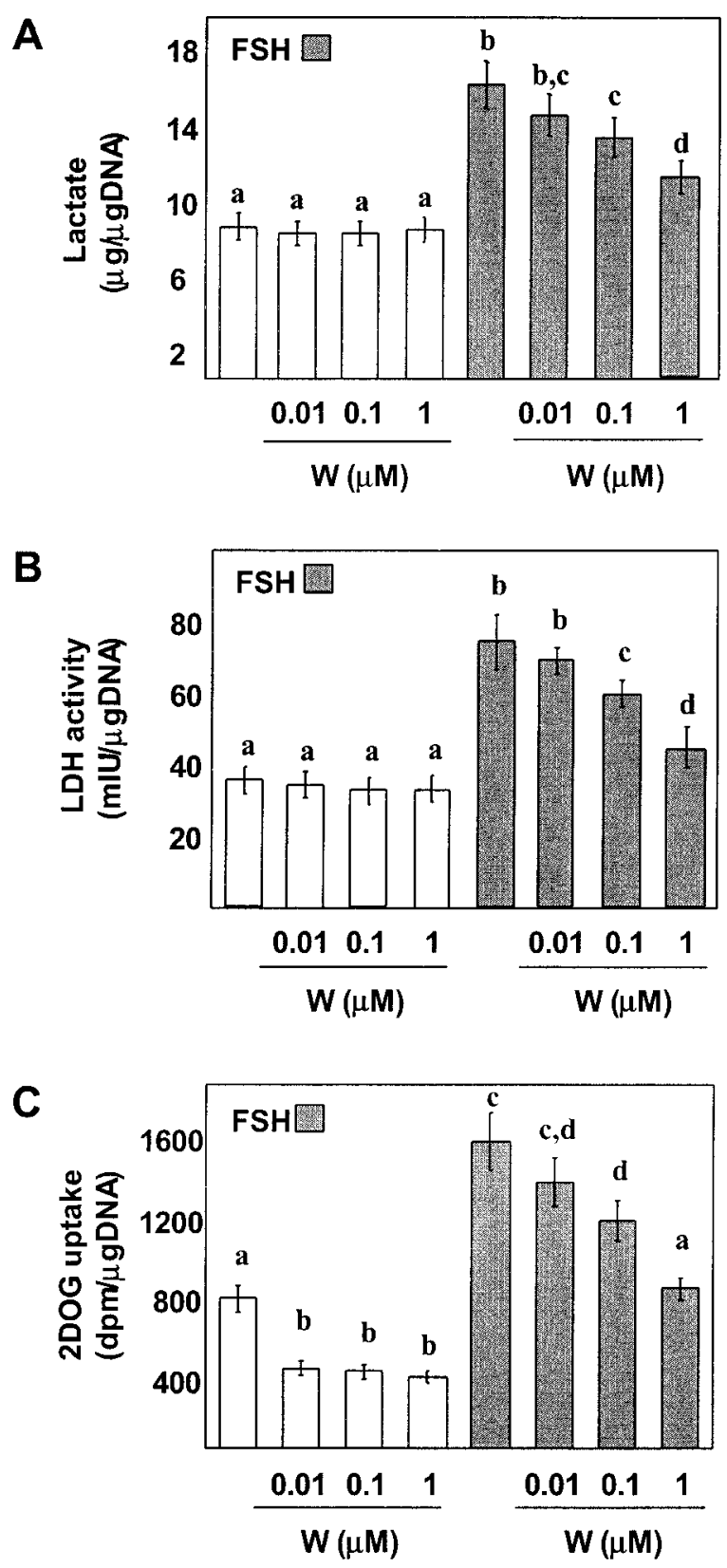

Figure 4 Wortmannin inhibits FSH stimulation of Sertoli cell lactate production, LDH activity and glucose uptake. (A) Sertoli cells were stimulated for $72 \mathrm{~h}$ (day 3 to day 6 ) with $100 \mathrm{ng} / \mathrm{ml} \mathrm{FSH}$ in the absence or presence of variable doses of wortmannin (W). Lactate was determined in the 72 -h conditioned media recovered on day 6. (B) Sertoli cells were stimulated for $72 \mathrm{~h}$ (day 3 to day 6) with $100 \mathrm{ng} / \mathrm{ml} \mathrm{FSH}$ in the absence or presence of variable doses of wortmannin. $\mathrm{LDH}$ activity was determined on cells harvested on day 6. (C) On day 5 of culture, Sertoli cells were maintained for 60 min under basal or FSH-stimulated $(100 \mathrm{ng} / \mathrm{ml})$ conditions in the absence or presence of different doses of wortmannin. Glucose uptake assay (2 DOG uptake) was performed after this incubation period. Results represent means \pm S.D. of triplicate incubations in one representative experiment out of three. Different letters indicate statistically significant differences $(P<0 \cdot 01)$.
Table 3 Effect of $\mathrm{H} 89$ and cycloheximide on basal and FSH-stimulated glucose uptake. On day 5, Sertoli cells were incubated without (Control) or with $10 \mu \mathrm{M} \mathrm{H} 89$ or $5 \mu \mathrm{M}$ cycloheximide (Chx) in the absence (Basal) or presence of $100 \mathrm{ng} / \mathrm{ml} \mathrm{FSH}$ for $60 \mathrm{~min}$. Glucose uptake assay was performed after this incubation period. Results represent means \pm S.D. of triplicate incubations in one representative experiment out of three

\begin{tabular}{lll} 
& \multicolumn{2}{l}{$\begin{array}{l}\text { Glucose uptake } \\
(\mathrm{dpm} / \mu \mathrm{gDNA})\end{array}$} \\
\cline { 2 - 2 } & \multicolumn{1}{c}{ Basal } & FSH \\
Control & $556 \pm 56^{\mathrm{a}}$ & $1235 \pm 81^{\mathrm{b}}$ \\
H89 $(10 \mu \mathrm{M})$ & $634 \pm 53^{\mathrm{a}}$ & $1182 \pm 37^{\mathrm{b}}$ \\
Chx $(5 \mu \mathrm{M})$ & $521 \pm 48^{\mathrm{a}}$ & $1110 \pm 79^{\mathrm{b}}$
\end{tabular}

Different letters indicate statistically significant differences $(P<0 \cdot 01)$.

Recently, a link between FSH binding to its receptor, cAMP and PI3K signaling pathway in granulosa cells at different stages of differentiation has been observed (Gonzalez-Robayna et al. 2000). The above mentioned investigation and many others obtained for the action of hormones in different cell types provide increasing evidence indicating that multiple cellular signaling cascades regulate cell function and that these signaling pathways are hormone- as well as cell-specific. The precise molecular and biochemical mechanisms involved in FSH regulation of Sertoli cell function remain largely unknown.

In this paper, we show that FSH increases P-PKB levels in a PI3K-dependent manner in rat Sertoli cells and that this regulation is closely related to Sertoli cell function. We have observed that FSH increases P-PKB levels and that two inhibitors of PI3K, wortmannin and Ly 294002, abolish the effect of FSH. Several speculations can be made on the possible mechanism(s) that may be utilized by FSH to regulate the PI3K/PKB pathway. Firstly, an FSH receptor protein bearing the features of a growth factor type I receptor in the mature testis has recently been cloned and identified (Babu et al. 1999). Occupancy of such a receptor by FSH may potentially result in activation of this pathway. Nevertheless, it should be noticed that the presence of this kind of receptor protein has not been unequivocally demonstrated in 20-day-old rat Sertoli cells. Secondly, another possible mechanism that may be involved in PI3K regulation by FSH is the one that utilizes the classic G-protein-coupled receptor and the freed $G \beta \gamma$ subunit. Again, no data are at present available to support the latter hypothesis. Lastly, considering that a similar increase in the levels of P-PKB is observed in cells stimulated with dbcAMP, it is tempting to speculate that the observed phenomenon is a consequence of elevated intracellular cAMP levels produced by FSH postactivation of adenylyl cyclase by $\mathrm{G} \alpha$ subunit. In support of the latter hypothesis we have observed parallel increments in cAMP and P-PKB levels produced by FSH stimulation. In addition, the lack of an inhibitory effect of H89 on 
FSH-stimulated P-PKB levels and the inhibitory effect of wortmannin and Ly 294002 on dbcAMP-stimulated P-PKB levels suggest that cAMP regulates P-PKB levels in a PKA-independent and PI3K-dependent manner. The exact mechanism by which cAMP regulates PI3K remains largely unknown. However, it is worth mentioning that Richards (2001) proposes that cAMP produced upon binding of several related glycoprotein hormones to their respective G-protein-coupled receptors binds to the cAMP-regulated guanine nucleotide exchange factor (cAMP-GEF) and activates PI3K. Although, at present, a link between cAMP, GEF and PI3K in rat Sertoli cells has not been demonstrated, the data obtained so far support the idea that stimulation of Sertoli cell PI3K by FSH may involve such a mechanism.

In analyzing the consequences of PI3K inhibition on Sertoli cell P-PKB levels and on Sertoli cell response to FSH, several interesting observations were made. Such observations were obtained by evaluating three wellknown parameters of Sertoli cell function that increase in response to FSH: $\gamma$-GTP activity, transferrin secretion and lactate production.

$\gamma$-GTP is a membrane-bound enzyme that is widely distributed in mammalian tissues. It has been suggested that, among other functions, it acts as a transport system for amino acids across the plasma membrane (Tate \& Meister 1981). In Sertoli cells its activity is stimulated by FSH and germ cell-secreted products (Schteingart et al. 1989). Several signal transduction pathways, not necessarily evoked by FSH, have been analyzed by their ability to regulate $\gamma$-GTP activity in rat Sertoli cells (Meroni et al. 1997, 1999, 2000). Transferrin is an iron transport protein secreted by Sertoli cells and is vital to the regulation and maintenance of spermatogenesis (Skinner \& Griswold 1980). In a similar way to that observed for $\gamma$-GTP activity, previous studies have demonstrated that FSH (Skinner \& Griswold 1980), growth factors (Skinner \& Griswold 1982, Han et al. 1993) and germ cellderived products (Le Magueresse et al. 1988) stimulate its secretion. In the present investigation we show that wortmannin, which inhibits PI3K activity and consequently $\mathrm{PKB}$ phosphorylation in response to $\mathrm{FSH}$, also partially inhibits FSH stimulation of $\gamma$-GTP activity and transferrin secretion. The inhibitory effect of wortmannin on $\gamma$-GTP activity was only observed at doses as high as $1 \mu \mathrm{M}$. Even though this dose of wortmannin inhibits neither basal $\gamma$-GTP levels nor cell viability in 72-h incubations, results obtained with this dose of the inhibitor should be interpreted with caution. In this respect, it has been demonstrated that high doses of wortmannin also inhibit other signaling enzymes (Fruman et al. 1998, Shepherd et al. 1998). However, the inhibitory effect of wortmannin on transferrin secretion occurs at doses well within the range of concentrations showing specific inhibitory effects on class I PI3K. This suggests the participation of PI3K and probably of PKB in a down- stream signaling event for the regulation of transferrin secretion by FSH. Ly 294002 and H89 decreased cell viability in 72-h incubations. For this reason these inhibitors could not be assayed to evaluate an alternative PI3K inhibitor and the relevance of the cAMP/PKA pathway respectively in the regulation of $\gamma$-GTP activity and of transferrin secretion. Several events downstream of $\mathrm{PI} 3 \mathrm{~K} / \mathrm{PKB}$ activation are related to protein synthesis (Vanhaesebroeck \& Alessi 2000) and increments in $\gamma$-GTP activity and in transferrin secretion involve de novo protein synthesis. In this way, it is not surprising that activation of this signaling pathway may be somehow related to the metabolic changes observed.

Carbohydrate metabolism in Sertoli cells presents some unique characteristics. Studies on glucose metabolism have shown that Sertoli cells actively metabolize glucose but the majority of it is converted to lactate and is not oxidized via the citric acid cycle (Robinson \& Fritz 1981, Grootegoed et al. 1986). In addition, germ cells, particularly postmeiotic germ cells, are unable to use glucose for their energetic metabolism and they do prefer lactate as an energy source (Mita \& Hall 1982). The importance of lactate for normal spermatogenesis has been demonstrated in a recent in vivo study (Courtens \& Plöen 1999). These observations have led to the conclusion that one of the most important Sertoli cell nurse functions is to provide lactate for the production of energy in spermatocytes and spermatids. It must be noticed that several biochemical steps may lead to increments in lactate production. Some of them like glucose transport and $\mathrm{LDH}$ activity play essential roles at the beginning of the process, providing the substrate, and at the end of the process, interconverting pyruvate and lactate. We have previously shown that FSH stimulates both processes in rat Sertoli cells (Riera et al. 2001); however, the signaling molecules involved in these actions of the hormone had not previously been investigated. The present study shows that FSH stimulation of lactate production and LDH activity are partially blocked in cells pre-incubated with the PI3K inhibitor, wortmannin. Again, doses of wortmannin showing the ability to decrease FSH action on these parameters are well within the range of concentrations considered to be specific for inhibition of PI3K. These results suggest that, in a similar way to that observed for transferrin secretion, a $\mathrm{PI} 3 \mathrm{~K} / \mathrm{PKB}$ signaling pathway participates in the FSH regulation of these parameters.

As for the regulation of glucose transport by FSH the relevance of a cAMP/PKA pathway was evaluated due to the fact that $\mathrm{H} 89$ does not change cell viability in 60-min incubations. Results obtained showing a lack of inhibitory effect of H89 on FSH-stimulated glucose uptake suggest that the cAMP/PKA pathway is not involved in glucose transport in Sertoli cells. On the other hand, the inhibition of glucose uptake induced by wortmannin under basal conditions and the ability of wortmannin to inhibit FSH stimulation of glucose uptake points to the fact that a 
PI3K-dependent pathway is essential to the process of glucose transport through the plasma membrane. These results are not surprising, as the relationship between a PI3K pathway and glucose transport has been extensively analyzed (Okada et al. 1994, Huppertz et al. 1996, Czech \& Corvera 1999). Nevertheless, the latter studies refer mainly to translocation to the plasma membrane of the glucose transporter GLUT4 and are referred to the mechanism of action of insulin and growth factors but not to that of FSH. Fewer studies have analyzed GLUT1 translocation to the plasma membrane but it apparently does occur (Samih et al. 2000). In rat Sertoli cells glucose transport is mediated mainly by the glucose transporter GLUT1, the only glucose transporter demonstrated so far in these cells (Ulisse et al. 1992). Our results suggest that the mechanism of action of FSH in rat Sertoli cells involves translocation of GLUT1 to the plasma membrane. The latter suggestion is based mainly on two observations that are somehow related: (a) changes in glucose uptake induced by FSH are observed after a short-term exposure to the hormone and (b) the protein synthesis inhibitor cycloheximide does not inhibit FSH stimulation of glucose uptake.

Altogether, the results presented in this investigation suggest an important role of a PI3K/PKB pathway in the mechanism of action utilized by FSH/cAMP to regulate Sertoli cell metabolism. In addition to PKB, other signaling pathways downstream of PI3K may be partly responsible for the observed effects of FSH on Sertoli cell function. However, as in most cases the metabolic changes were accompanied by changes in the levels of P-PKB it is tempting to speculate that this serine/threonine kinase plays a meaningful role in the mechanism of action of FSH/cAMP in rat Sertoli cells.

\section{Acknowledgements}

We thank A Parlow from NIDDK for the gift of ovine FSH. The photographic assistance of Oscar Rodriguez and the technical help of Mercedes Astarloa are gratefully acknowledged. We also thank Celia Nieto for revising our English usage and Carolina Mondillo for cAMP determinations. This work was supported by grants from CONICET, Beca de Investigación ' $\mathrm{R}$. Carrillo-A. Oñativia' and the Agencia Nacional de Promoción Científica y Tecnológica, Argentina. S B Meroni and S B Cigorraga are established investigators of CONICET.

\section{References}

Alessi D, Andjelkovic M, Caudwell B, Cron P, Morrice N, Cohen P \& Hemmings B 1996 Mechanism of activation of protein kinase B by insulin and IGF-I. EMBO Journal 15 6541-6551.

Babu PS, Jiang L, Sairam AM, Touyz RM \& Sairam MR 1999 Structural features and expression of an alternatively spliced growth factor type I receptor for FSH signaling in the developing ovary. Molecular and Cellular Biology Research Communications 2 21-27.

Bellacosa A, Testa J, Staal S \& Tsichlis P 1991 A retroviral oncogene, akt, encoding a serine-threonine kinase containing an SH2-like region. Science 254 274-277.

Cameron MR, Foster JS, Bukovsky A \& Wimalasena J 1996 Activation of mitogen-activated protein kinases by gonadotropins and cyclic adenosine $5^{\prime}$-monophosphates in porcine granulosa cells. Biology of Reproduction 55 111-119.

Cass LA, Summers SA, Prendergast GV, Backer JM, Birbaum MJ \& Meinkoth JL 1999 Protein kinase A-dependent and -independent signaling pathways contribute to cyclic AMP-stimulated proliferation. Molecular and Cellular Biology 19 5882-5891.

Coffer P \& Woodgett J 1991 Molecular cloning and characterization of a novel putative protein serine kinase related to cAMPdependent and protein kinase C families. European Journal of Biochemistry 201 475-481.

Coffer P, Jin J \& Woodgett J 1998 Protein kinase B (c-Akt): a multifunctional mediator of phosphatidylinositol 3-kinase activation. Biochemical Journal 335 1-13.

Courtens JL \& Plöen L 1999 Improvement of spermatogenesis in adult cryptorchid rat testis by intratesticular infusion of lactate. Biology of Reproduction 61 154-161.

Crepieux P, Marion S, Martinat N, Fafeur V, Vern YL, Kerboeuf DF \& Reiter E 2001 The ERK-dependent signaling is stage-specifically modulated by FSH during primary Sertoli cell maturation. Oncogene 20 4696-4709.

Czech MP \& Corvera S 1999 Signaling mechanisms that regulate glucose transport. Journal of Biological Chemistry 274 1865-1868.

Das S, Maizels ET, DeManno D, St Claire E, Adam SA \& Hunzicker-Dunn M 1996 A stimulatory role of cyclic adenosine $3^{\prime}, 5^{\prime}$-monophosphate in follicle-stimulating hormone-activated mitogen-activated protein kinase signaling pathway in rat ovarian granulosa cells. Endocrinology 137 967-974.

Delfino F \& Walker WH 1998 Stage-specific nuclear expression of NF-KB in mammalian testis. Molecular Endocrinology 12 1696-1707.

Filippa N, Sable C, Filloux C, Hemmings B \& Van Obberghen E 1999 Mechanism of protein kinase B activation by cAMPdependent protein kinase. Molecular and Cellular Biology 19 4989-5000.

Fruman DA, Meyers RE \& Cantley LC 1998 Phosphoinositide kinases. Annual Review of Biochemistry 67 481-507.

Gnessi L, Fabbri A \& Spera G 1997 Gonadal peptides as mediators of development and functional control of the testis: an integrated system with hormones and environment. Endocrine Reviews 18 541-609.

Gonzalez-Robayna I, Falender A, Ochsner S, Firestone G \& Richards J 2000 FSH stimulates phosphorylation and activation of protein kinase $\mathrm{B}$ (PKB/Akt) and serum and glucocorticoid-induced kinase (Sgk): evidence for a kinase-independent signaling by FSH in granulosa cells. Molecular Endocrinology 14 1283-1300.

Gorczynska E \& Handelsman D 1991 The role of calcium in FSH signal transduction in Sertoli cells. Journal of Biological Chemistry 266 23739-23744.

Grasso P \& Reichert L 1989 FSH receptor-mediated uptake of ${ }^{45} \mathrm{Ca}^{2+}$ by proteoliposomes and cultured rat Sertoli cells: evidence for involvement of voltage-activated and voltage-independent calcium channels. Endocrinology 125 3029-3036.

Griswold MD 1993 Actions of FSH on mammalian Sertoli cells. In The Sertoli Cell, pp 493-508. Eds LD Russell \& MD Griswold. Clearwater, Florida, USA: Cache River Press.

Grootegoed JA, Oonk RB, Jansen R \& van der Molen HJ 1986 Metabolism of radiolabelled energy-yielding substrates by rat Sertoli cells. Journal of Reproduction and Fertility 77 109-118.

Han IS, Sylvester SR, Kim KH, Schelling ME, Venkateswaran S, Blanckaert VD, McGuinness MP \& Griswold MD 1993 Basic fibroblast growth factor is a testicular germ cell product which may regulate Sertoli cell function. Molecular Endocrinology 7 889-897. 
Handelsman DJ, Spaliviero JA, Kidston E \& Robertson DM 1989 Highly polarized secretion of inhibin by Sertoli cells in vitro. Endocrinology 125 721-729.

Huppertz C, Schwartz C, Becker W, Horn F, Heinrich PC \& Joost HG 1996 Comparison of the effects of insulin, PDGF, interleukin-6 and interferon- $\gamma$ on glucose transport in 3T3-L1 cells: lack of cross-talk between tyrosine kinase receptors and JAK/STAT pathways. Diabetologia 39 1432-1439.

Jannini E, Ulisse S \& Cecconi S 1994 Follicle-stimulating hormone-induced phospholipase A2 activity and eicosanoid generation in rat Sertoli cells. Biology of Reproduction 51 140-145.

Jones P, Jacubowicz T, Pitossi F, Mauer F \& Hemmings B 1991 Molecular cloning and identification of a serine/threonine protein kinase of the second messenger subfamily. PNAS $\mathbf{8 8} 4171-4175$.

Labarca C \& Paigen K 1980 A simple, rapid and sensitive DNA assay procedure. Analytical Biochemistry 102 344-352.

Laemmli UK 1970 Cleavage of structural proteins during the assembly of the head of bacteriophage T4. Nature 227 680-685.

Lambert A, Talbot JA, Mitchell R \& Robertson WR 1991 Inhibition of protein kinase $\mathrm{C}$ by staurosporine increases estrogen secretion by rat Sertoli cells. Acta Endocrinologica 125 286-290.

Le Magueresse B, Pineau C, Guillou F \& Jegou B 1988 Influence of germ cells upon transferrin secretion by rat Sertoli cells in vitro. Journal of Endocrinology 118 13-16.

Meroni SB, Cánepa DF, Pellizzari EH, Schteingart HF \& Cigorraga SB 1997 Regulation of $\gamma$-glutamyl transpeptidase activity by $\mathrm{Ca}^{2+}$ and protein kinase C-dependent pathways in Sertoli cells. International Journal of Andrology 20 189-194.

Meroni SB, Cánepa DF, Pellizzari EH, Schteingart HF \& Cigorraga SB 1999 Effect of $\mathrm{N}$-acetylsphingosine (c2) and ceramidase inhibitor (1S,2R)-D-erythro-2-(N-myristoylamino)-1-phenyl1-propanol on the regulation of Sertoli cell function. Journal of Andrology 20 619-625.

Meroni SB, Suburo M \& Cigorraga SB 2000 Interleukin-1 $\beta$ regulates nitric oxide production and $\gamma$ glutamyl transpeptidase activity in Sertoli cells. Journal of Andrology 21 855-861.

Mita M \& Hall PF 1982 Metabolism of round spermatids from rats: lactate as the preferred substrate. Biology of Reproduction 26 445-455.

Monaco L, Adamo S \& Conti M 1988 FSH modulation of phosphoinositide turnover in the immature rat Sertoli cell in culture. Endocrinology 123 2032-2039.

Moore RK, Otsuka F \& Shimasaki S 2001 Role of ERK1/2 in the differential synthesis of progesterone and estradiol by granulosa cells. Biochemical and Biophysical Research Communications 289 796-800.

Okada T, Kawano Y, Sakakibara T, Hazeki O \& Ui M 1994 Essential role of phosphatydylinositol 3-kinase in insulin-induced glucose transport and antilipolysis in rat adipocytes. Journal of Biological Chemistry 269 3568-3573.

Orlowsky M \& Meister A $1963 \gamma$-Glutamyl-p-nitroanilide: a new convenient substrate for determination and study of $\mathrm{L}-$ and
D- $\gamma$-glutamyltranspeptidase activities. Biochimica et Biophysica Acta $\mathbf{7 3}$ 679-681.

Orth JM 1982 Proliferation of Sertoli cell in fetal and postnatal rats: a quantitative autoradiographic study. Anatomical Record 203 485-492.

Porter AC \& Vaillancourt RR 1998 Tyrosine kinase receptor-activated signal transduction pathways which lead to oncogenesis. Oncogene 17 1343-1352.

Rameh L \& Cantley LC 1999 The role of phosphoinositide 3-kinase lipid products in cell function. Journal of Biological Chemistry 274 8347-8350.

Richards JS 2001 New signaling pathways for hormones and cyclic adenosine $3^{\prime}, 5^{\prime}$-monophosphate action in endocrine cells. Molecular Endocrinology 15 209-218.

Riera MF, Meroni SB, Gomez GE, Schteingart HF, Pellizzari EH \& Cigorraga SB 2001 Regulation of lactate production by FSH, IL-1 $\beta$ and TNF $\alpha$ in rat Sertoli cells. General and Comparative Endocrinology $12288-97$.

Robinson R \& Fritz I 1981 Metabolism of glucose by Sertoli cells in culture. Biology of Reproduction 24 1032-1041.

Samih N, Hovsepian S, Aouani A, Lombardo D \& Fayet G 2000 Glut-1 translocation in FRTL-5 thyroid cells: role of phosphatydylinositol 3-kinase and N-glycosylation. Endocrinology 141 4146-4155.

Schteingart HF, Rivarola MA \& Cigorraga SB 1989 Hormonal and paracrine regulation of $\gamma$-glutamyltranspeptidase in rat Sertoli cells. Molecular and Cellular Endocrinology 67 73-80.

Shepherd PR, Withers DJ \& Siddle K 1998 Phosphoinositide 3-kinase: the key switch mechanism in insulin signaling. Biochemical Journal 333 471-490.

Skinner MK \& Griswold MD 1980 Sertoli cells synthesize and secrete transferrin-like protein. Journal of Biological Chemistry 255 9523-9525.

Skinner MK \& Griswold MD 1982 Secretion of testicular transferrin by cultured Sertoli cells is regulated by hormones and retinoids. Biology of Reproduction 27 211-221.

Tang X \& Downes P 1997 Purification and characterization of G $\beta \gamma$-responsive phosphoinositide 3-kinases from pig platelet cytosol. Journal of Biological Chemistry 272 14193-14199.

Tate SS \& Meister A $1981 \gamma$-Glutamyl transpeptidase: catalytic, structural and functional aspects. Molecular and Cellular Biochemistry 39 357-368.

Ulisse S, Jannini EA, Pepe M, De Matteis S \& D'Armiento M 1992 Thyroid hormone stimulates glucose transport and GLUT1 mRNA in rat Sertoli cells. Molecular and Cellular Endocrinology 87 131-137.

Vanhaesebroeck B \& Alessi D 2000 The PI3K-PDK1 connection: more than just a road to pkB. Biochemical Journal 346 561-576.

Received 19 April 2002

Accepted 24 April 2002 